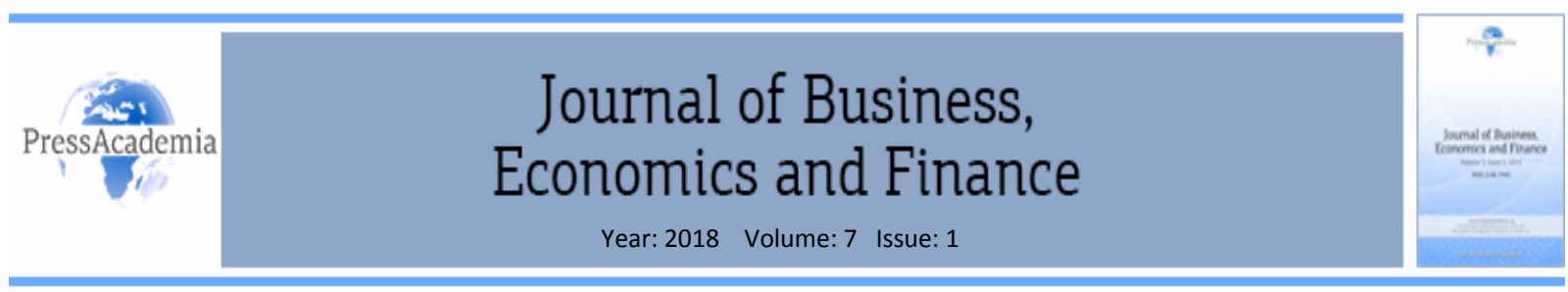

\title{
THE MONETARY TRANSMISSION MECHANISM: EVIDENCE FROM TURKEY
}

\author{
DOI: 10.17261/Pressacademia.2018.795 \\ JBEF- V.7-ISS.1-2018(6)-p.64-75
}

\author{
Ahmet Incekara ${ }^{1}$, Akmyrat Amanov ${ }^{2}$ \\ ${ }^{1}$ Istanbul University, The Institute of Social Sciences. Istanbul, Turkey, \\ incekara@istanbul.edu.tr, ORCID: 0000-0003-0224-2006. \\ ${ }^{2}$ Istanbul University, The Institute of Social Sciences. Istanbul, Turkey, \\ akmyratamanov@gmail.com, ORCID: 0000-0002-4269-7809
}

\section{To cite this document}

Incekara, A., Amanov A.(2018). The monetary transmission mechanism: evidence from Turkey. Journal of Business, Economics and Finance (JBEF), V.7(1), p.64-75.

Permanent link to this document: http://doi.org/10.17261/Pressacademia.2018.795

Copyright: Published by PressAcademia and limited licensed re-use rights only.

\begin{abstract}
Purpose- The CBRT announced in April 2010 that included financial stability in its target function, and in November 2010 started implementing modified monetary policy strategy with new monetary policy tools. In this study, the effectiveness of modified monetary policy was questioned. Thus, primarily the impacts of intermediate targets on price stability, then the impacts of policy instruments on intermediate targets have been investigated.

Methodology- The Johansen cointegration test and VECM are used to show long-run relationships and causality between variables. Then, Granger causality test is used to examine short-run causality between the variables.

Findings- In the long run, while credit supply and USD exchange rate affect price level, the average funding rate doesn 't affect the price level. Credit supply, USD exchange rate and average funding rate affect TUFE in the short run. In addition, in the long run, while the required reserve ratio and interest corridor affect credit supply; average funding rate and policy interest rate doesn 't affect credit supply. Moreover, in the long run, policy instruments do not have an impact on the USD exchange rate. Reserve requirements cause changes in credit supply, and average funding rate causes changes in USD exchange rate in the short run.

Conclusion- The exchange rate channel and the credit channel is valid in Turkey. In addition, while required reserves and interest rate corridor have a predictable impact on the credit supply, no policy instrument has a predictable effect on the exchange rate.
\end{abstract}

Keywords: Monetary transmission mechanisms, Johansen cointegration test, monetary policy instrument JEL Codes: C32, E52, E58

\section{INTRODUCTION}

Central banks implementing the inflation targeting strategy entered into new policy search after the global financial crisis. The fact that the old strategy targeted only price stability led to neglecting financial stability, which is important for macroeconomic stability. Especially in the developing countries with current account deficit problem, the single targetsingle instrument strategy caused to trade off on important macroeconomic indicators. Developing countries experienced short-term capital inflows during periods when global risk appetite is raised. This stimulated import demand by making the domestic currency more valuable. Moreover, short-term capital inflows increased the domestic credit supply, allowing the banking system to give more credits. Commodity prices increased sharply. Most importantly, the current account deficit, which is badly funded, started to increase. The main source of funding for current account deficits was short-term capital investments and portfolio investments. The occurrence of all these situations made the Turkish economy fragile (Başçı and Kara, 2011).

The CBRT could not respond to this situation only with one policy instrument. The low interest rate policy would discourage short-term capital inflows, but at the same time it would stimulate domestic demand. Such a situation led Central Bank, which was targeting price stability, to ignore financial stability. Therefore, the CBRT started searching new monetary policy strategy. During the years of 2001-2010, the CBRT applied the inflation targeting strategy. This New Keynesian Approach, which is easy to understand and communicate, covered the single target-single instrument (price stability-short term 
interest rate) policy. The CBRT announced in April 2010 that included financial stability in its target function, and in November 2010 started implementing modified monetary policy strategy with new monetary policy tools.

In this study, the effectiveness of modified monetary policy was questioned. Thus, primarily the impacts of intermediate targets on price stability, then the impacts of policy instruments on intermediate targets have been investigated. Firstly, the new target function, instrument function and transmission mechanisms will be introduced to readers for a better understanding of the concept. Then, some empirical works on this subject will be shown. Finally, the relationship between the instruments and the targets will be examined by establishing the Johansen cointegrating model. Findings will be discussed both theoretically and statistically.

\section{LITERATURE REVIEW}

\subsection{Modified Monetary Policy Strategy}

The CBRT entered into new policy search after the global financial crisis; because the short-term interest rate was not sufficient to achieve both price stability and financial stability. In this chapter, the new target and instrument function of CBRT, and emiprical studies will be briefly explained.

\subsubsection{Target Function}

The CBRT had only price stability goal before the global financial crisis. Modified monetary policy strategy consists two goals; price stability and financial stability.

The first objective of the Central Bank is price stability, which is defined as low and stable inflation. Price stability: avoids excessive investment in the financial sector, stabilizes the real tax revenue, and reduces the uncertainty of the future price level (Sheshinski and Weiss, 1977; Fischer and Modigliani, 1978). Although there is a trade-off between inflation (wage inflation) and unemployment due to the supply curve that is flat in the short run, the long-run expectation shifts the supply curve to an upright position and the exchange relationship between inflation and unemployment is lifted (Phillips, 1958; Mankiw, 2001; Friedman, 1977). Price stability is consistent with long-run objectives such as high employment, stability in financial markets and stability in foreign exchange markets.

Another objective of the Central Bank is financial stability, which is defined as the existence of a powerful and efficient financial system which is able to ensure an efficient allocation of savings into investments. The CBRT notes that some intermediate targets must be met in order to ensure financial stability. These intermediate targets are; control of credit supply growth and control of short-term capital inflows. Some empirical works show that increase in current account deficit and poorly financing of current account deficit trigger serious economic crises in the Turkish economy (Özcan, Özlale, Sarıkaya, 2007). When the crises of 1994, 2001 and 2008 were examined closely, it is clearly seen that the current account deficit of the Turkish economy started to increase, and financing of current account deficits switched from the long-term sources to the short-term sources.

\subsubsection{Instrument Function}

The central bank uses three criteria when choosing policy instruments (monetary base or interest rate): the instrument should be observable and measurable, controllable, and should have a predictable influence on the targets (Poole, 1970, Friedman, 1990). The policy instrument should be quickly observable and accurately measurable so that the central bank's political stance can be reflected quickly. In order for the policy instrument to be able to see useful functions, the central bank must have effective control over the instrument.

One of the policy instruments of the CBRT is the policy interest rate. It is expected that the policy interest rate will influence final target by expectation channel. The expected low policy interest rate, has a contractionary effect on short-term capital inflows, while has reviving effect on domestic demand.

The other policy instrument is an interest rate corridor, which is an area between the overnight lending rate and the overnight borrowing rate set by the CBRT. The CBRT can affect both targets by modifying corridor parameters. The Central Bank can increase volatility and inconsistency by expanding corridor range. Therefore, short-term capital inflows will be restricted because of lowered return/risk ratio. In addition, the uncertainty in the interest rate corridor causes banks to be more cautious about credit supply, thus causing domestic demand to contract (Başçı and Kara, 2011). In January 2017, the CBRT forced to a late liquidity window by stopping funding at the overnight lending rate. Thus, interest rate corridor became an area between LLW lending grate and the overnight borrowing rate.

Liquidity management is a new instrument of CBRT. The CBRT can diversify the official interest rates with actual interest rates. The CBRT is able to implement neutral liquidity management by providing the liquidity in the banking system as much as it needs; is able to implement contractionary liquidity management by providing liquidity under its need; and is able to implement expansionary liquidity management by providing liquidity over its needs. Diversifying of interest rates enables 
the CBRT to implement the funding composition strategy (Binici, Kara, Özlü, 2016). Under normal conditions, it is expected that CBRT funds all liquidity needs through the weekly repo, which is the policy interest rate. Therefore, the actual interest rates will follow closely policy interest rates. However, the CBRT can deliberately diversify actual interest rates and policy interest rates. In contractionary liquidity management strategy, the CBRT enforces banking system to borrow from more expensive sources. In this way, it increases the cost of banks' short term liabilities. If the CBRT provides part of liquidity needs from weekly repo and part of it from marginal funding, then the actual interest rates will be higher than the official interest rates. Briefly, this strategy allows the CBRT to change its political stance without changing official interest rates.

The reserve requirements instrument is another policy instrument, which the CBRT started to use after a long time. Reserve requirements are requirements that banks must hold at the central bank in reserve. Reserve requirements are used for three reasons: (1) reserve, (2) liquidity management, (3) monetary control. The reserve role is to act as a guarantee against extraordinary withdrawals. Today, this role has lost its significance. Liquidity management role has also lost its significance due to the fact that open market operations are a more effective instrument to control liquidity. The importance of reserve requirements lies in the monetary central role (Alper and Tiryaki, 2011). The Central Bank started using reserve requirements because this instrument allowed the Central Bank to implement contractionary monetary policy without affecting short-term capital inflows.

\subsubsection{Transmission Mechanism}

The power and interaction process of the effects of decisions on monetary policy on economic indicators remains uncertain. Bernanke and Gertler (1995) described this process of uncertainty as a black box. The mechanism that removes this uncertainty from the monetary policy and explains dynamic interactions of monetary policy is called the monetary transmission mechanism. This study covers traditional monetary transmission mechanisms.

\subsubsection{Interest Rate Transmission Mechanism}

There are two approaches in examining monetary actions. The first approach is an examination of the importance of money in economic activities (the reduced form) and the second is the examination of the total demand influencing channels of the monetary policy (structural form). One of the foremost of the structural form approach has been the traditional interest rate channel. According to the traditional interest rate channel, the central bank's expansionary monetary policy lowers nominal interest rates by increasing money supply. Since prices are assumed to be sticky, the change in nominal interest rates has the same effect on real interest rates. A decline in real interest rates lowers cost of capital, thus increasing investment expenditures. Residential and durable consumer expenditures are also included in investment expenditures. The final result of the increase in total investment expenditures and consumption expenditures is the increase in total demand and total production. However, when the interest rate flexibility of investments is zero and the interest rate flexibility of the money demand is infinite, this mechanism does not work (Hicks, 1937).

There are other transfer mechanisms besides the traditional interest rate channel. These can be divided into three groups: Asset price channel, credit channel, and expectations channel. The asset price channel shows the effects of changes in the relative prices of financial and real assets on total expenditure and production. The asset price channel is based on the assumption that the financial market is perfect, as is the traditional interest channel. The asset price channel can be examined in three categories. Wealth effect channel is the first asset price channel (Ando and Modigliani, 1963; Modigliani and Brumberg, 1954). According to this channel, stocks have an important role in the consumers' lifetime resources; therefore, changes in stock prices affect consumption expenditures. The second wealth effect channel is Tobin's q channel (Tobin, 1969). According to this channel, changes in stock prices have an impact on investment expenditures by affecting the market value of firms. Stock prices will not be included in this econometric study since stocks are relatively weak saving instruments in the Turkish economy.

The last wealth effect channel is an exchange rate channel. Nowadays, with the opening of economies to foreign markets, flexible exchange rates have started to be used more widely. Switching to flexible exchange rate systems has increased the interest in Mundell (1963) and Fleming (1962) models. The exchange rate channel is trying to explain the effect of the relationship between the monetary policy and the exchange rate on the total output and prices. The exchange rate channel works more efficiently in (1) economies using a flexible exchange rate system, (2) economies where capital flows have a high interest rate elasticity, (3) economies where the degree of openness is high (exports and imports have a higher share of GDP). When the monetary authority applies the expansionary monetary policy, domestic real interest rates fall. This situation lowers the demand of foreigners to domestic assets. With falling demand, the price of national assets goes down and the national currency depreciates. The depreciation of the national currency increases net exports and total demand.

In countries such as Turkey, where input goods are imported intensively, changes in the exchange rate can affect financial stability as well. The low interest policy causes a rise in the exchange rate. Therefore, costs of input import goods increase. Increased costs are reflected in prices, and general level of prices increases. The situation becomes more interesting in high 
interest rate policy. High interest rates accelerate the entry of short-term capital movements, leading to the valuation of domestic currency. This leads to a decrease in net exports, in other words, an increase in current account deficit. Moreover, financing the current account with short-term sources can make the economy extremely fragile.

The credit channel may have an important role in consumption and investment decision since households in Turkey heavily get credit from banks. The first channel of credit view is the bank lending channel (Bernanke and Gertler, 1995), (Bernanke and Blinder, 1988) and (Friedman, 1968). The channel focuses on the role of banks in the economy and especially in the financial markets. Contrary to the previous channels, there are three distinct and completely non-substitute actives. These are money, securities and bank loans. In addition, importance is attached to the difference between borrowers. Especially small firms that are not able to export securities and which are not reliable enough to be funded from non-bank are affected by the contradictory monetary policy. This channel works more effectively in countries where the banking sector is the main funding source for companies. When the monetary authority applies the expansionary monetary policy, the bank reserves and deposits will increase and the amount of credit that can be used will increase. In this way, small and mediumsized firms will be able to get credits more easily. Therefore more easily and realize the investments they are planning. This will increase investment and consumption expenditures and eventually the total output will increase. On the contrary situation, bank reserves and deposits will decrease. In this situation, banks will either sell securities or shorten supply of credit. In the situation that the supply of credit is reduced, small and medium-sized firms will not be able to obtain credit and will not be able to make the investment expenditures they are planning. As a result, the total output will decrease.

The expectation channel is the final interest rate channel. The central bank has power over controlling short-term interest rates. Banks can meet their liquidity needs at the central bank if they do not prefer to borrow or lend at the interbank market. Interest rates on treasury bills and bonds are also can be controlled by the central bank through expectations. Long-term interest rates are not based on current short-term interest rates, but rather on the expectations of short-term interest rates. The central bank should have accountability for officials, transparency in the policy making process, and open communication for efficient results of this channel. A central bank can lead the market by pointing signals about future policy interest rates; and can adjust long-term interest rates (Woodford, 2001).

\subsubsection{Reserve Requirements Transmission Mechanism}

The first transmission mechanism of reserve requirements is cost channel. Cost of reserve requirements can be found by multiplying deposit interest and reserve requirements. This cost affects banks' funding costs, and banks try to reflect this change in the credit interest and deposit interest. Cost channel works efficiently when central bank can affect the difference between credit interest and deposit interest by changing reserve requirements. When the required reserves change, the costs of the liabilities of the banks increase. Banks will try to compensate this cost by widening the difference between credit interest and deposit interest. In order for this channel to be effective, (1) the payment of interest on the required reserves should be terminated, and (2) the free deposits of the banks must be less than required reserves (Alper and Tiryaki, 2011).

The other reserve requirements channel is a liquidity risk channel. A central bank can change the banks' short-term needs and behavior by changing reserve requirements. When the liquidity withdrawn from banks by reserve requirements, banks can compensate it by borrowing again. This will make banks more dependent on central bank resources. Although the credit levels of the banks remain the same, maturity mismatch will arise. Banks will have to reflect this liquidity risk at credit interests, or they will have to shorten credits to reduce their dependence on short-term resources. In addition, the central bank is able to make this channel more efficient by increasing uncertainty and volatility in interest rates (Alper and Tiryaki, 2011).

\subsection{Empirical Studies}

Many empirical studies have been carried out on the functioning of monetary transmission mechanisms. Smets and Wouters (1999), studied Germany for the period 1975-1997 by utilizing the VAR model. According to their study, the exchange rate channel is valid. After the monetary tightening, the exchange rate appreciated and as result import goods were replaced by domestic goods. Demand for export goods and domestic demand fell, and real GDP declined.

Camarero et al (2002), studied Spain for the period 1986-1998 by using the Cointegration Analysis. According to their study, traditional interest rate channel and exchange rate channel are valid. Monetary tightening increases short and longterm interest rates. Moreover, contractionary monetary policy appreciates exchange rate and causes a decrease in total output.

Nagayasu (2007), analyzed Japan for the period 1970-2006 by utilizing the VAR model. According to study, the exchange rate channel is valid. Monetary expansion has lowered the value of the Yen, but the finding that this change affects the total output is inadequate. 
Zhang and Sun (2006), studied China using General Equilibrium model. According to study, the traditional interest rate channel is valid. Consumption goods are classified as durable and non-durable. The expansion of the consumer credit market has enabled the operation of the interest channel with the credit channel.

Mehrotra (2007), studied Japan, Hong Kong and China for the period 1991-2004 by using Structural VAR model. According to study, the exchange rate channel is valid in Japan and Hong Kong. The exchange rate channel does not work in China due to capital controls.

Ornek (2009), analyzed Turkey for the period 1990-2006 by utilizing VAR model. According to study, the traditional interest rate channel and the exchange rate channel are valid. The asset price channel and the bank lending channel are not valid.

Cengiz (2009), stated that empirical studies cannot be carried out because the countries have different institutional and economic structures and degree of openness.

Buyukakın, Cengiz and Turk (2009), studied Turkey for the period 1990-2007 by using VAR model. According to study, the exchange rate channel is important. Monetary policy shocks cause significant changes in prices.

Cambazoglu and Gunes (2011), studied Turkey and Argentina for the period 2003-2010 by setting VAR model. According to study, the monetary base channel is valid in Turkey and the bank lending channel is valid in Argentina.

Cambazoglu and Karaalp (2012), studied Turkey for the period 2003-2010 by using VAR model. According to study, the exchange rate channel is important.

Akbas, Zeren and Ozekicioglu (2013), studied Turkey for the period 2005-2013 by applying VAR model. According to study, traditional interest rate channel and the exchange rate channel affect the industrial production, thus the total output is affected in the short term.

Saracoglu and Kose (1999), studied Turkey for the period 1980-1996 by using VAR model. According to study, the exchange rate channel is valid.

Kasapoglu (2007), analyzed Turkey for the period 1990-2006 by setting VAR model. According to study, the traditional interest rate channel is working effectively. The exchange rate only affects the overall level of prices, not on real activity. The empirical findings that asset price channel and credit channels operate is insufficient.

Incekara, Demez and Ustaoglu (2012), studied Turkey for the period 1989-2011 by utilizing Cointegration and VECM model. According to study, in the long run, the Fischer effect is valid in Turkey.

Binici, Kara, Ozlu (2016), studied Turkey for the period 2010-2014 by applying Panel Data Analysis. According to study, the effects of policy instruments on credit and deposit interest rates examined. Actual interest rates are more determinative on credit and deposit interest rates, rather than policy interest rates.

Incekara and Amanov (2017), studied Turkey for the period 1990-2016 by setting Cointegration and VECM model. The effectiveness of the bank lending channel in the Turkish economy has been questioned. According to study, the money supply is endogenous in the sample period. Monetary aggregates may not be an optimal monetary policy instrument.

\section{DATA AND METHODOLOGY}

In this study, the effectiveness of modified monetary policy was questioned. Thus, primarily the impacts of intermediate targets on price stability, then the impacts of policy instruments on intermediate targets have been investigated. TUFE, KREDI, USD, OFF, REPO, GFARK and ZKO variables were used to set up the model. TUFE represents the general price level; KREDI represents domestic credit supply provided by banks; USD represents the USD exchange rate; OFF represents the average funding rate of CBRT; REPO represents one week repo interest rate; GFARK represents interest rate corridor which defined as the difference between central bank lending and borrowing rates; and ZKO represents simple average of the domestic required reserve ratios. The study covers periods of 2010M11-2017M08, and the frequency of time series is monthly. The time series is taken from CBRT EVDS system, and the CBRT statistics. The logarithm of the variables is taken to establish the relation of flexibility among variables.

In order to find the appropriate model, it was first tested whether the variables contain a unit root. Since the economic model generally has higher autoregressive processes, the ADF unit root test is applied. When this test is applied, the appropriate number of lags included in the model is determined with the help of the Akaike and Schwarz information criteria. The results are shown in Table 1. 
Table 1: Unit Root Test Results for Series

\begin{tabular}{|c|c|c|c|c|}
\hline & \multicolumn{4}{|c|}{ ADF } \\
\hline & Level & Level Prob. & 1st Difference & 1st Difference Prob. \\
\hline LNOFF & -1.478987 & 0.5392 & -7.917444 & 0.0000 \\
\hline LNREPO & -1.922421 & 0.3206 & $-\mathbf{8 . 5 7 1 5 7 5}$ & 0.0000 \\
\hline LNGFARK & -1.413236 & 0.5718 & $-\mathbf{- 7 . 6 6 5 6 0 8}$ & 0.0000 \\
\hline LNZKO & -1.891042 & 0.3347 & -6.330430 & 0.0000 \\
\hline LNUSD & -0.483170 & 0.8882 & $\mathbf{- 6 . 8 2 2 4 4 0}$ & 0.0000 \\
\hline LNKREDi & -2.501080 & 0.3270 & $-\mathbf{- 8 . 5 3 2 3 2 6}$ & 0.0000 \\
\hline LNTUFE & -3.452962 & 0.0516 & -4.868728 & 0.0009 \\
\hline MacKinnon (1996) one sided p-values.
\end{tabular}

* Significant at the $5 \%$ level

According to the results of the unit root test, it is observed that when the first difference of the series is taken, they become stationary. Time series are integrated I (1) in the first degree. Although all series are not stationary at normal levels, there may be a long-run relationship between the variables due to being integrated at the first difference level. Thus the Johansen approach $(1988,1995)$ was applied as a method of cointegration analysis.

\section{FINDINGS AND DISCUSSIONS}

\subsection{Model 1 - The Effects of Intermediate Targets on Price Stability}

The Johansen cointegration test accepts all variables in the model as endogenous. For this reason, estimates should be made with the help of vector and matrix. The VAR model was estimated, and the values of the lag length criteria were found. Three of these criteria (AIC, FPE and LR) showed that 5 lags of variables should be taken. According to these three criteria, the appropriate model is VAR (5) and the appropriate error correction model is VECM (4). The results of the information criteria are shown in Table 2.

Table 2: Appropriate Lag Selection for Var Model

\begin{tabular}{|c|c|c|c|c|c|c|}
\hline Lag & LogL & LR & FPE & AIC & SC & HQ \\
\hline 0 & 299.2649 & NA & $4.96 \mathrm{e}-09$ & -7.770129 & -7.647459 & -7.721105 \\
\hline 1 & 772.8614 & 884.8777 & $2.93 \mathrm{e}-14$ & -19.81214 & $-19.19879 *$ & $-19.56702^{*}$ \\
\hline 2 & 787.9566 & 26.61522 & $3.01 \mathrm{e}-14$ & -19.78833 & -18.68430 & -19.34711 \\
\hline 3 & 804.1820 & 26.89993 & $3.02 \mathrm{e}-14$ & -19.79426 & -18.19955 & -19.15694 \\
\hline 4 & 820.9973 & 26.10806 & $3.00 \mathrm{e}-14$ & -19.81572 & -17.73033 & -18.98230 \\
\hline 5 & 839.7644 & $\mathbf{2 7 . 1 6 2 9 1 *}$ & $\mathbf{2 . 8 7 e - 1 4} *$ & $\mathbf{- 1 9 . 8 8 8 5 4}$ & -17.31246 & -18.85901 \\
\hline 6 & 854.0000 & 19.10557 & $3.14 \mathrm{e}-14$ & -19.84210 & -16.77535 & -18.61648 \\
\hline
\end{tabular}

* shows appropriate lag length

It is important that the short-term VAR model and the long-term cointegrating model contain intercept and trend. Five different models can be set considering the intercept and trend:

1- There are no intercept and trend in both long-term and short-term models. $\left(\delta_{1}=\delta_{2}=\mu_{1}=\mu_{2}=0\right)$ Model: $\Delta \mathrm{Z}_{\mathrm{t}}=\mathbb{\Gamma}_{1} \Delta \mathrm{Z}_{\mathrm{t}-1}+$ $\mathbb{\Gamma}_{2} \Delta \mathrm{Z}_{\mathrm{t}-2}+\ldots+\mathbb{\Gamma}_{\mathrm{p}-1} \Delta \mathrm{Z}_{\mathrm{t}-\mathrm{p}+1}+\boldsymbol{\alpha} \beta \mathrm{Z}_{\mathrm{t}-1}+\varepsilon_{\mathrm{t}}$

2- There is intercept only in long-term model. There is no trend in both models. $\left(\delta_{1}=\delta_{2}=\mu_{2}=0\right)$ Model: $\Delta Z_{\mathrm{t}}=\mathbb{\Gamma}_{1} \Delta \mathrm{Z}_{\mathrm{t}-1}+$ $\mathbb{\Gamma}_{2} \Delta \mathrm{Z}_{\mathrm{t}-2}+\ldots+\mathbb{\Gamma}_{\mathrm{p}-1} \Delta \mathrm{Z}_{\mathrm{t}-\mathrm{p}+1}+\alpha\left(\beta \mu_{1}\right)\left(\mathrm{Z}_{\mathrm{t}-1} \mathbf{1}\right)+\varepsilon_{\mathrm{t} .}$

3- Both short-term and long-term models have intercept. Both short-term and long-term models don 't have trend. $\left(\delta_{1}=\delta_{2}=0\right)$ Model: $\Delta Z_{\mathrm{t}}=\mathbb{\Gamma}_{1} \Delta \mathrm{Z}_{\mathrm{t}-1}+\mathbb{\Gamma}_{2} \Delta \mathrm{Z}_{\mathrm{t}-2}+\ldots+\mathbb{\Gamma}_{\mathrm{p}-1} \Delta \mathrm{Z}_{\mathrm{t}-\mathrm{p}+1}+\alpha\left(\beta \mu_{1}\right)\left(\mathrm{Z}_{\mathrm{t}-1} \quad \mathbf{1}\right)+\mu_{2}+\varepsilon_{\mathrm{t}}$.

4- The long-term model has both intercept and trend. The short-term model has only intercept. $\left(\delta_{2}=0\right)$ Model: $\Delta \mathrm{Z}_{\mathrm{t}}=\mathbb{\Gamma}_{1} \Delta \mathrm{Z}_{\mathrm{t}-1}+\mathbb{\Gamma}_{2} \Delta \mathrm{Z}_{\mathrm{t}-2}+\ldots+\mathbb{\Gamma}_{\mathrm{p}-1} \Delta \mathrm{Z}_{\mathrm{t}-\mathrm{p}+1}+\alpha\left(\beta \mu_{1} \delta_{1}\right)\left(\begin{array}{lll}\mathrm{Z}_{\mathrm{t}-1} & 1 & \mathrm{t}\end{array}\right)+\mu_{2}+\varepsilon_{\mathrm{t}}$.

5- The long-term model has intercept and quadratic trend. The short-term model has intercept and trend. 
Table 3: Johansen $(1988,1995)$ Cointegration Test Results

\begin{tabular}{|cccc|}
\hline \multicolumn{4}{c|}{$\lambda_{\text {trace }}$ Statistics } \\
\hline Hypotheses & $\begin{array}{c}\text { Eigenvalue } \\
\left(\lambda_{i}\right)\end{array}$ & $\lambda_{\text {trace }}$ & Critical Value \\
\% 5 \\
\hline$H_{0}: r=0, H_{1}: r=1$ & 0.452943 & $\mathbf{7 7 . 7 2 5 5 8 *}$ & 54.07904 \\
$H_{0}: r \leq 1, H_{1}: r=2$ & 0.183619 & 30.07266 & 35.19275 \\
$H_{0}: r \leq 2, H_{1}: r=3$ & 0.119721 & 14.04560 & 20.26184 \\
$H_{0}: r \leq 3, H_{1}: r=4$ & 0.049034 & 3.971853 & 9.164546 \\
\hline & \multicolumn{3}{c}{$\lambda_{\max }$ statistics } \\
\hline Hypotheses & Eigenvalue & $\lambda_{\max }$ & Critical Value \\
\hline$H_{0}: r=0, H_{1}: r \geq 1$ & $\left(\lambda_{i}\right)$ & & 28.58808 \\
$H_{0}: r \leq 1, H_{1}: r \geq 2$ & 0.452943 & $47.65292 *$ & 22.29962 \\
$H_{0}: r \leq 2, H_{1}: r \geq 3$ & 0.183619 & 16.02706 & 15.89210 \\
$H_{0}: r \leq 3, H_{1}: r \geq 4$ & 0.119721 & 10.07375 & 9.164546 \\
\hline
\end{tabular}

* Significant at the $5 \%$ level.

While the generation of Model 1 is difficult in real life, interpretation of the Model 5 is very difficult. The use of Model 1 and Model 5 is unlikely and uncommon in economic studies (Sevuktekin and Cinar, 2014). It is determined that the appropriate model is Model 2 and the rank of the $\Pi$ matrix is equal to one. In model 2, there is no trend in the long-run cointegration model; there are no intercept and trend in the short-run VECM model.

At the later stage, the appropriate rank for the model needs to be determined. The rank of the $\Pi$ matrix is calculated by the $\lambda \max$ and $\lambda$ trace statistics in the Model 2 frame and the results are given in Table 3.

Critical values are MacKinnon-Haug-Michelis (1999) p-values. When the above values are compared with these values, it is seen that the null hypotheses of the maximum eigenvalue and trace test statistics are rejected according to the level of $5 \%$ significance level. Variables in the model are cointegrated. Since the matrix of $\Pi$ is equal to the rank one, there is one cointegrating relationship between variables.

The weak exogeneity test was applied. Weak exogeneity means that a variable is only affected by its lagged values. In order to make LNTUFE, LNKREDI, LNUSD and LNOFF variables weakly exogenous: it is necessary that LNTUFE variable in the first equation, LNTUFE variable in the second equation, LNUSD variable in the third equation, and LNOFF variable in the fourth equation be a function of their own lagged values respectively. Thus, if the matrix $\alpha$ is zero, then the variables are weakly exogenous because the effect of the parameters of the cointegration vector will be reduced from the corresponding equation. The results of the weak exogeneity test are given in Table 4. According to the results of the weak exogeneity test, LNTUFE and LNKREDI variables are endogenous, while LNUSD and LNOFF variables are exogenous.

Table 4: Weak Exogeneity Test Results

\begin{tabular}{|c|c|c|c|}
\hline Variables & Null Hypothesis & LR (rank=4) & Prob. \\
\hline LNTUFE & $\mathbf{H}_{\mathbf{0}}: \mathbf{a}_{\mathbf{1 1}}=\mathbf{0}$ & 16.92329 & 0.000039 \\
\hline LNKREDi & $\mathbf{H}_{\mathbf{0}}: \mathbf{a}_{\mathbf{2 1}}=\mathbf{0}$ & 5.189135 & 0.022729 \\
\hline LNUSD & $\mathbf{H}_{\mathbf{0}}: \mathbf{a}_{\mathbf{3 1}}=\mathbf{0}$ & $\mathbf{3 . 7 2 1 2 5 6}$ & $\mathbf{0 . 0 5 3 7 2 4}$ \\
\hline LNOFF & $\mathbf{H}_{\mathbf{0}}: \mathbf{a}_{\mathbf{4 1}}=\mathbf{0}$ & $\mathbf{0 . 0 1 2 6 6 6}$ & $\mathbf{0 . 9 1 0 3 9 1}$ \\
\hline
\end{tabular}

\footnotetext{
* Significant at the $5 \%$ level.
}

LNTUFE model was established to find the effects of intermediate targets on price stability. The findings of the model are given in Table 5: 
Table 5: Normalized Cointegrating Coefficients (Long-Run Elasticity)

\begin{tabular}{|cccccc|}
\hline & TUFE & KREDi & USD & OFF & C \\
\hline $\begin{array}{c}\text { Normalized } \\
\begin{array}{c}\text { Coefficients } \\
\text { Standard Error }\end{array}\end{array}$ & 1.0000 & $-0.340961^{*}$ & $-0.142446^{*}$ & -0.010943 & $1.871182^{*}$ \\
\hline * Significant at the 5\% level. & & $(0.04437)$ & $(0.07074)$ & $(0.03524)$ & $(0.88671)$ \\
\hline
\end{tabular}

\section{LNUFE $=\mathrm{C}+0.34 \mathrm{LNKREDI}+0.14 \mathrm{LNUSD}$}

According to the findings, while credit supply and USD exchange rate affect the general level of prices, the average funding rate doesn't affect price level. Expansion of credit supply stimulates domestic demand by leading rise in consumption and investment expenditures. A $10 \%$ increase in KREDI leads to a $3.4 \%$ increase in TUFE. Rise in USD exchange rate, increases the general level of prices by increasing the costs of imported goods. A $10 \%$ increase in USD leads to $1.4 \%$ increase in TUFE. Let's give an example to illustrate the situation better. In an economy where the increase in credit supply is $20 \%$, and the increase in USD exchange rate is $20 \%$; the expected inflation rate is $9.6 \%$. KREDI and USD variables are both statistically and theoretically significant. In addition, changes in the general level of prices cause credit supply. There is a mutual causality between the inflation rate and credit supply.

Table 6: Vector Error-Correction Model Prediction Results: Vecm (4)

\begin{tabular}{|ccccc|}
\hline & TUFE & KREDi & USD & OFF \\
\hline $\begin{array}{c}\text { VECM } \\
\text { Coefficients }\end{array}$ & $0.040444^{*}$ & $-0.046057^{*}$ & -0.068093 & -0.047530 \\
Standard Error & $(0.01602)$ & $(0.00895)$ & $(0.03530)$ & $(0.41642)$ \\
\hline
\end{tabular}

In the vector error correction model, it is proved that shocks that can occur in the long-run equilibrium can be corrected. The coefficients in the error correction model were negative and statistically significant as expected. These coefficients indicate the rate at which the short-run deviations resulting from the non-stationary series are adjusted in the next period. The short-run imbalance that occurs in TUFE is adjusted approximately in twenty five months; the short-run imbalance that occurs in KREDI is adjusted in twenty five months to the long-run equilibrium level.

Table 7: Granger Causality Test Results:

\begin{tabular}{|cccc|}
\hline & KREDi & USD & OFF \\
\hline & Dependent variable: D(LNTUFE) \\
Chi-sq & $13.01693^{*}$ & $25.49425^{*}$ & $10.64606^{*}$ \\
Prob. & 0.0112 & 0.0000 & 0.0308 \\
\hline
\end{tabular}

* Significant at the $5 \%$ level.

Granger causality test was applied to find the short term causality relationship. According to the test, credit supply, USD exchange rate and average funding rate affect general level of prices in the short term.

\subsection{Model 2 - The Effects of Policy Instruments on Intermediate Targets}

The VAR model was estimated, and the values of the lag length criteria were found. According to LR and FPE criteria, the appropriate model is VAR (3) and the appropriate error correction model is VECM (2). The results of the information criteria are shown in Table 8. 
Table 8: Appropriate Lag Selection for Var Model

\begin{tabular}{|ccccccc|}
\hline Lag & LogL & LR & FPE & AIC & SC & HQ \\
\hline $\mathbf{0}$ & 238.5665 & NA & $8.86 \mathrm{e}-11$ & -6.120172 & -5.936167 & -6.046635 \\
$\mathbf{1}$ & 831.4110 & 1076.481 & $3.84 \mathrm{e}-17$ & -20.77397 & $-19.48594^{*}$ & $-20.25921^{*}$ \\
$\mathbf{2}$ & 879.5707 & 79.84384 & $2.84 \mathrm{e}-17$ & -21.09397 & -18.70190 & -20.13798 \\
$\mathbf{3}$ & 928.0595 & $72.73312^{*}$ & $2.14 \mathrm{e}-17^{*}$ & -21.42262 & -17.92652 & -20.02541 \\
$\mathbf{4}$ & 965.4443 & 50.17436 & $2.25 \mathrm{e}-17$ & $-21.45906^{*}$ & -16.85893 & -19.62063 \\
$\mathbf{5}$ & 1001.234 & 42.38234 & $2.63 \mathrm{e}-17$ & -21.45352 & -15.74936 & -19.17386 \\
$\mathbf{6}$ & 1028.490 & 27.97311 & $4.20 \mathrm{e}-17$ & -21.22341 & -14.41522 & -18.50253 \\
\hline
\end{tabular}

* shows appropriate lag length

It is determined that the appropriate model is Model 2 and the rank of the $\Pi$ matrix is equal to two. In model 2 , there is no trend in the long-run cointegration model; there are no intercept and trend in the short-run VECM model. The rank of the $\Pi$ matrix is calculated by the $\lambda \max$ and $\lambda$ trace statistics in the Model 2 frame and the results are given in Table 9 below.

Table 9: Johansen $(1988,1995)$ Cointegration Test Results

\begin{tabular}{|cccc|}
\hline \multicolumn{4}{c|}{$\lambda_{\text {trace }}$ Statistics } \\
\hline Hypotheses & $\begin{array}{c}\text { Eigenvalue } \\
\left(\lambda_{i}\right)\end{array}$ & $\lambda_{\text {trace }}$ & $\begin{array}{c}\text { Critical Value } \\
\% ~ 5\end{array}$ \\
\hline$H_{0}: r=0, H_{1}: r=1$ & 0.568479 & $\mathbf{1 6 2 . 7 6 7 8}$ & 0.0000 \\
$H_{0}: r \leq 1, H_{1}: r=2$ & 0.428306 & 96.37317 & 0.0008 \\
$H_{0}: r \leq 2, H_{1}: r=3$ & 0.297820 & 52.20024 & 0.0728 \\
$H_{0}: r \leq 3, H_{1}: r=4$ & 0.153861 & 24.26861 & 0.4456 \\
\hline \multicolumn{4}{c}{$\lambda_{\text {max }}$ statistics } \\
\hline Hypotheses & Eigenvalue & $\lambda_{\text {max }}$ & Critical Value \\
& $\left(\lambda_{i}\right)$ & & 40.95680 \\
\hline$H_{0}: r=0, H_{1}: r \geq 1$ & 0.568479 & 66.39467 & 34.80587 \\
$H_{0}: r \leq 1, H_{1}: r \geq 2$ & 0.428306 & 44.17294 & 28.58808 \\
$H_{0}: r \leq 2, H_{1}: r \geq 3$ & 0.297820 & 27.93162 & 22.29962 \\
$H_{0}: r \leq 3, H_{1}: r \geq 4$ & 0.153861 & 13.19863 & \\
\hline
\end{tabular}

* Significant at the $5 \%$ level.

The weak exogeneity test was applied. The results of the weak exogeneity test are given in Table 10. According to the test, LNKREDI and LNZKO variables are endogenous; LNUSD, LNOFF, LNREPO and LNGFARK variables are exogenous. For this reason, only the KREDI model will be set up.

Table 10: Weak Exogeneity Test Results

\begin{tabular}{|c|c|c|c|}
\hline Variables & Null Hypothesis & LR (rank=2) & Prob. \\
\hline LNKREDi & $H_{0}: a_{11}=0, H_{0}: a_{12}=0$ & 24.46891 & 0.000005 \\
\hline LNUSD & $H_{0}: a_{21}=0, H_{0}: a_{22}=0$ & 5.405076 & 0.067035 \\
\hline LNOFF & $H_{0}: a_{31}=0, H_{0}: a_{32}=0$ & 1.413746 & 0.493184 \\
\hline LNREPO & $H_{0}: a_{41}=0, H_{0}: a_{42}=0$ & 0.504597 & 0.777013 \\
\hline LNGFARK & $H_{0}: a_{51}=0, H_{0}: a_{52}=0$ & 3.208764 & 0.201014 \\
\hline LNZKO & $H_{0}: a_{61}=0, H_{0}: a_{62}=0$ & 23.91185 & 0.000006 \\
\hline
\end{tabular}

* Significant at the $5 \%$ level.

The findings of KREDI model are given in Table 11.

Table 11: Normalized Cointegrating Coefficients (Long-Run Elasticity)

\begin{tabular}{|c|c|c|c|c|c|c|}
\hline & KREDi & USD & OFF & REPO & GFARK & ZKO \\
\hline \multicolumn{7}{|c|}{ KREDI MODEL } \\
\hline $\begin{array}{l}\text { Normalized } \\
\text { Coefficients }\end{array}$ & 1.0000 & 0.0000 & -0.470163 & 0.454388 & $0.294745^{*}$ & 2.454170 \\
\hline Standard Error & & & (0.32777) & $(0.33970)$ & (0.11205) & (0.55094) \\
\hline
\end{tabular}

\footnotetext{
* Significant at the $5 \%$ level.

LNKREDI $=\mathrm{C}-0.29$ LNGFARK -2.45 LNZKO
} 
According to the findings, while the required reserve ratio and interest corridor affect credit supply; average funding rate and policy interest rate doesn't affect credit supply. Rise in a reserve required ratio, contract amount of credits that can be given. A $10 \%$ rise in ZKO leads to a $25 \%$ contraction in KREDI. In addition, broadening interest corridor increases volatility and uncertainty in interest rates, leading to a contraction in credit supply. A $10 \%$ increase in GFARK leads to a $3 \%$ contraction in KREDI. Let's give an example to illustrate the situation better. In an economy where the rise in the reserve required ratio is from $5 \%$ to $5.5 \%$, contracts credit supply by $25 \%$. Modifying of range of corridor from $6-8 \%$ to $4-8 \%$, contracts credit supply by $29 \%$. ZKO and GFARK variables are both statistically and theoretically significant. In addition the USD model is not established, due to this variable is exogenous. In the long run, policy instruments do not have an impact on the USD exchange rate.

Table 12: Vector Error-Correction Model Prediction Results: Vecm (2)

\begin{tabular}{|ccccccc|}
\hline & KREDi & USD & OFF & REPO & GFARK & ZKO \\
\hline VECM & & & & & & \\
Coefficients & $0.041216^{*}$ & -0.029659 & -0.029486 & -0.058673 & -0.089767 & $-0.167059^{*}$ \\
Standard Error & $(0.00917)$ & $(0.02160)$ & $(0.08001)$ & $(0.07081)$ & $(0.11619)$ & $(0.02481)$ \\
\hline
\end{tabular}

* Significant at the $5 \%$ level.

The coefficients in the error correction model were negative and statistically significant as expected. These coefficients indicate the rate at which the short-run deviations resulting from the non-stationary series are adjusted in the next period. The short-run imbalance that occurs in KREDI is adjusted approximately in twenty four months; the short-run imbalance that occurs in ZKO is adjusted in six months to the long-run equilibrium level.

Granger causality test was applied to find the short term causality relationship. According to test, reserve required ratio causes changes in credit supply, and average funding rate causes changes in USD exchange rate in the short term. The findings are given in Table 13.

Table 13: Granger Causality Test Results:

\begin{tabular}{|c|c|c|c|c|c|c|}
\hline & KREDI & USD & OFF & REPO & GFARK & ZKO \\
\hline \multicolumn{7}{|c|}{ Dependent variable: D(LNKREDI) } \\
\hline Chi-sq & & 2.231547 & 4.701622 & 3.193872 & $5.942132 *$ & $19.00958^{*}$ \\
\hline Prob. & & 0.3277 & 0.0953 & 0.2025 & 0.0512 & 0.0001 \\
\hline \multicolumn{7}{|c|}{ Dependent variable: $\mathrm{D}(\mathrm{LNUSD})$} \\
\hline Chi-sq & 2.111280 & & $9.178997 *$ & 2.223339 & 1.872301 & 5.336628 \\
\hline Prob. & 0.3480 & & 0.0102 & 0.3290 & 0.3921 & 0.0694 \\
\hline
\end{tabular}

\footnotetext{
* Significant at the $5 \%$ level.
}

\section{CONCLUSION}

The CBRT announced in April 2010 that included financial stability in its target function; and in November 2010 started implementing modified monetary policy strategy with new monetary policy tools. In this study, the effectiveness of modified monetary policy was questioned. Thus, primarily the impacts of intermediate targets on price stability, then the impacts of policy instruments on intermediate targets have been investigated. . As a research method, the Johansen cointegration test and VECM are used to show long-run relationships and causality between variables and Granger causality test is used to examine short-run causality between the variables. According to findings, in the long run, while credit supply and USD exchange rate affect price level, the average funding rate does not affect the general level of prices. Expansion of credit supply, stimulates domestic demand by leading rise in consumption and investment expenditures. Rise in USD exchange rate, increases the general level of prices by increasing the costs of imported goods. A $10 \%$ increase in KREDI leads to a $3.4 \%$ increase in TUFE. A $10 \%$ increase in USD exchange rate leads to $1.4 \%$ increase in TUFE. Moreover, credit supply, USD exchange rate and average funding rate affect TUFE in the short run.

According to findings, in the long run, the required reserve ratio and interest corridor affect credit supply; while the average funding rate and policy interest rate does not affect credit supply. Rise in a reserve required ratio, contracts amount credits that can be given by cost and liquidity risk channel. A $10 \%$ rise in ZKO leads to a $25 \%$ contraction in KREDI. In addition, broadening interest corridor increases volatility and uncertainty in interest rates, leading to a contraction in credit supply. A $10 \%$ increase in GFARK leads to a $3 \%$ contraction in KREDI. Moreover, in the long run, policy instruments do not 
have an impact on the USD exchange rate. Reserve required ratio causes changes in credit supply, and average funding rate causes changes in USD exchange rate in the short term.

\section{REFERENCES}

Ahmed, S., and Islam, M. E. (2004). The monetary transmission mechanism in Bangladesh: Bank lending and exchange rate channels. The Bangladesh Development Studies, 31-87.

Akbaş, Y. E., Zeren, F., and Özekicioğlu, H. (2013). Türkiye'de Parasal Aktarım Mekanizması: Yapısal VAR Analizi. Cumhuriyet Üniversitesi İktisadi ve İdari Bilimler Dergisi, 14(2), 187-198.

Alper, K., and Tiryaki, T. (2011). Zorunlu karşılıkların para politikasındaki yeri. CBT Economic Note, (11/08).

Ando, A., and Modigliani, F. (1963). The" life cycle" hypothesis of saving: Aggregate implications and tests. The American economic review, 53(1), 55-84

Basci, E., and Kara, H. (2011). Finansal istikrar ve para politikası. İktisat İşletme ve Finans, 26(302), 9-25.

Bernanke, B. S., and Blinder, A. S. (1988). Credit, money, and aggregate demand. The American Economic Review, Vol. 78, No. 2, $435-439$.

Bernanke, B. S. (1993). Credit in the Macroeconomy. Quarterly Review-Federal Reserve Bank of New York, $18,50-50$.

Bernanke, B. S., and Gertler, M. (1995). Inside the black box: the credit channel of monetary policy transmission (No. w5146). National bureau of economic research.

Binici, M., Kara, H., and Özlü, P. (2016). Unconventional Interest Rate Corridor and the Monetary Transmission: Evidence from Turkey. TCMB Çalışma Tebliği, (16/08)

Buyukakın, F., Cengiz, V., and Turk, A. (2013). PARASAL AKTARIM MEKANIZMASI: TÜRKIYE'DE DÖVIZ KURU KANALININ VAR ANALIZi. Dokuz Eylül Üniversitesi İktisadi ve İdari Bilimler Fakültesi Dergisi, 24(1).

Camarero, M., Ordóñez, J., and Tamarit, C. R. (2002). Monetary transmission in Spain: a structural cointegrated VAR approach. Applied Economics, 34(17), 2201-2212.

Cambazoglu, B., and Gunes, S. (2011). Monetary Transmission Mechanism in Turkey and Argentina. International Journal of Economics and Finance Studies, 3(2), 23-33.

Cambazoglu, B., and Karaalp, S. H. (2012). The effect of monetary policy shock on employment and output: the case of Turkey. Economics, Management and Financial Markets, 7(4), 311.

Cengiz, V. (2009). PARASAL AKTARIM MEKANIZMASI işLEYişi VE AMPiRiK BULGULAR. Erciyes Üniversitesi İktisadi ve İdari Bilimler Fakültesi Dergisi, (33), 225-247.

Fischer, S., and Modigliani, F. (1978). Towards an understanding of the real effects and costs of inflation. Review of World Economics, $114(4), 810-833$.

Fleming, J. M. (1962). Domestic financial policies under fixed and under floating exchange rates. Staff Papers, 9(3), 369-380.

Friedman, B. M. (1990). Targets and instruments of monetary policy. Handbook of monetary economics, 2, 1185-1230.

Friedman, M., and Schwartz, A. J. (1975). Money and business cycles. In The state of monetary economics (pp. 32-78). NBER.

Hicks, J. R. (1937). Mr. Keynes and the" classics"; a suggested interpretation. Econometrica: Journal of the Econometric Society, $147-159$.

Incekara, A., Demez, S., and Ustaoğlu, M. (2012). Validity of Fisher effect for Turkish economy: cointegration analysis. Procedia-Social and Behavioral Sciences, 58, 396-405.

Incekara A., Amanov A. (2017). Optimal policy instrument selection in monetary policy: Endogeneity of money supply. Journal of business, economics and finance, 6(2), 61-69.

Johansen, S. (1988). Statistical analysis of cointegration vectors. Journal of economic dynamics and control, 12(2-3), 231-254.

Johansen, S. (1995). Identifying restrictions of linear equations with applications to simultaneous equations and cointegration. Journal of econometrics, 69(1), 111-132.

Kasapoğlu, Ö. (2007). Parasal Aktarım Mekanizmaları: Türkiye İçin Uygulama. Uzmanlık Yeterlilik Tezi. Ankara: Türkiye Cumhuriyet Merkez Bankası.

Mankiw, N. G. (2001). The inexorable and mysterious tradeoff between inflation and unemployment. The Economic Journal, 111(471), 4561.

Mehrotra, A. N. (2007). Exchange and interest rate channels during a deflationary era-Evidence from Japan, Hong Kong and China. Journal of Comparative Economics, 35(1), 188-210. 
Modigliani, F., and Brumberg, R. (1954). Utility analysis and the consumption function: An interpretation of cross-section data. Franco Modigliani, 1.

Mundell, R. A. (1963). Capital mobility and stabilization policy under fixed and flexible exchange rates. Canadian Journal of Economics and Political Science/Revue canadienne de economiques et science politique, 29(4), 475-485.

Nagayasu, J. (2007). Empirical analysis of the exchange rate channel in Japan. Journal of International Money and Finance, 26(6), 887-904.

Örnek, i. (2009). Türkiye'de parasal aktarım mekanizması kanallarının işleyişi. Maliye Dergisi, 156, 104-125.

Özcan, K. M., Özlale, Ü., and Sarıkaya, Ç. (2006). Sources of growth and the output gap for the Turkish economy. Contributions to Economic Analysis, 278, 237-266.

Phillips, A. W. (1958). The relation between unemployment and the rate of change of money wage rates in the United Kingdom, 186119571. Economica, 25(100), 283-299.

Poole, William. "Optimal choice of monetary policy instruments in a simple stochastic macro model." The Quarterly Journal of Economics 84.2 (1970): 197-216.

Saraçoğlu, B., and KÖSE, N. (1999). Vektör Otoregresyon Yaklaşımı ile Enflasyonla Mücadelede Politika Seçimi: Türkiye Örneği 80-96. İktisat İsletme ve Finans, 14(159), 12-27.

Sevüktekin, M., and Çınar, M. (2014). Ekonometrik Zaman Serileri Analizi, Dora Yayınclık, 4. Baskı, Bursa.

Sheshinski, E., and Weiss, Y. (1977). Inflation and costs of price adjustment. The Review of Economic Studies, 44(2), 287-303.

Smets, F., and Wouters, R. (1999). The exchange rate and the monetary transmission mechanism in Germany. De Economist, 147(4), 489521.

Tobin, J. (1969). A general equilibrium approach to monetary theory. Journal of money, credit and banking, 1(1), 15-29.

Woodford, M. (2001). Monetary policy in the information economy (No. w8674). National Bureau of Economic Research.

Zhang, Y., and Sun, G. (2006). China's consumer credit sector expansion and monetary transmission mechanism: What should China's central bank do?. Journal of Chinese Political Science, 11(1), 79-93. 